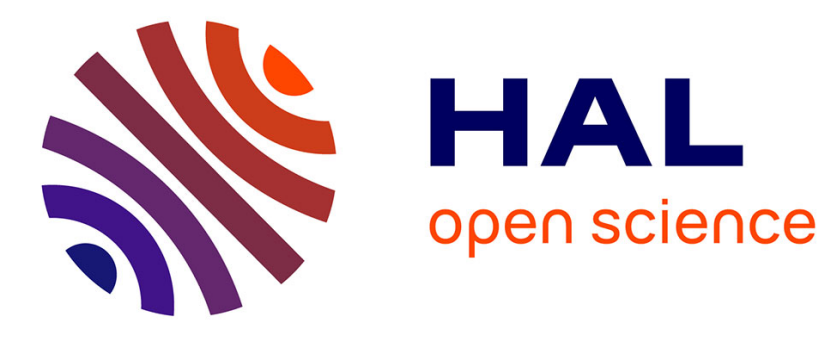

\title{
Excitatory GABA in rodent developing neocortex in vitro.
}

Sylvain Rheims, Marat Minlebaev, Anton Ivanov, Alfonso Represa, Rustem Khazipov, Gregory L. Holmes, Yehezkel Ben-Ari, Yuri Zilberter

\section{- To cite this version:}

Sylvain Rheims, Marat Minlebaev, Anton Ivanov, Alfonso Represa, Rustem Khazipov, et al.. Excitatory GABA in rodent developing neocortex in vitro.. Journal of Neurophysiology, 2008, 100 (2), pp.609-19. 10.1152/jn.90402.2008 . inserm-00483487

\section{HAL Id: inserm-00483487 https://www.hal.inserm.fr/inserm-00483487}

Submitted on 14 May 2010

HAL is a multi-disciplinary open access archive for the deposit and dissemination of scientific research documents, whether they are published or not. The documents may come from teaching and research institutions in France or abroad, or from public or private research centers.
L'archive ouverte pluridisciplinaire HAL, est destinée au dépôt et à la diffusion de documents scientifiques de niveau recherche, publiés ou non, émanant des établissements d'enseignement et de recherche français ou étrangers, des laboratoires publics ou privés. 


\title{
Excitatory GABA in Rodent Developing Neocortex In Vitro
}

\author{
Sylvain Rheims, ${ }^{1}$ Marat Minlebaev, ${ }^{1}$ Anton Ivanov, ${ }^{1}$ Alfonso Represa, ${ }^{1}$ Rustem Khazipov, ${ }^{1}$ Gregory L. Holmes, ${ }^{2}$ \\ Yehezkel Ben-Ari, ${ }^{1}$ and Yuri Zilberter ${ }^{1}$ \\ ${ }^{1}$ Institut de Neurobiologie de la Mediterranee, Institut National de la Santé et de la Recherche Médicale U901, Université de la \\ Méditerranée, Marseille, France; and ${ }^{2}$ Department of Neurology, Dartmouth Medical School, Lebanon, New Hampshire
}

Submitted 26 March 2008; accepted in final form 3 May 2008

\begin{abstract}
Rheims S, Minlebaev M, Ivanov A, Represa A, Khazipov R, Holmes GL, Ben-Ari Y, Zilberter Y. Excitatory GABA in rodent developing neocortex in vitro. J Neurophysiol 100: 609-619, 2008. First published May 21, 2008; doi:10.1152/jn.90402.2008. GABA depolarizes immature cortical neurons. However, whether GABA excites immature neocortical neurons and drives network oscillations as in other brain structures remains controversial. Excitatory actions of GABA depend on three fundamental parameters: the resting membrane potential $\left(E_{\mathrm{m}}\right)$, reversal potential of GABA $\left(E_{\mathrm{GABA}}\right)$, and threshold of action potential generation $\left(V_{\text {thr }}\right)$. We have shown recently that conventional invasive recording techniques provide an erroneous estimation of these parameters in immature neurons. In this study, we used noninvasive single $N$-methyl-D-aspartate and GABA channel recordings in rodent brain slices to measure both $E_{\mathrm{m}}$ and $E_{\mathrm{GABA}}$ in the same neuron. We show that GABA strongly depolarizes pyramidal neurons and interneurons in both deep and superficial layers of the immature neocortex (P2-P10). However, GABA generates action potentials in layer 5/6 (L5/6) but not L2/3 pyramidal cells, since L5/6 pyramidal cells have more depolarized resting potentials and more hyperpolarized $V_{\text {thr. }}$. The excitatory GABA transiently drives oscillations generated by L5/6 pyramidal cells and interneurons during development (P5-P12). The NKCC1 co-transporter antagonist bumetanide strongly reduces $\left[\mathrm{Cl}^{-}\right]_{\mathrm{i}}$ GABA-induced depolarization, and network oscillations, confirming the importance of GABA signaling. Thus a strong GABA excitatory drive coupled with high intrinsic excitability of L5/6 pyramidal neurons and interneurons provide a powerful mechanism of synapsedriven oscillatory activity in the rodent neocortex in vitro. In the companion paper, we show that the excitatory GABA drives layer-specific seizures in the immature neocortex.
\end{abstract}

\section{N T R O D U C T I O N}

Immature neurons readily generate network driven patterns in a wide range of brain structures and animal species (Adelsberger et al. 2005; Ben-Ari et al. 1989; Corlew et al. 2004; Galli and Maffei 1988; Garaschuk et al. 2000; Khazipov et al. 2001; Meister et al. 1991; Owens and Kriegstein 1998; Yuste et al. 1992). Several factors converge to faciltiate the generation of early oscillations including the depolarizing and excitatory actions of GABA (Ben-Ari 2002; Ben-Ari et al. 1989, 2007), high-input resistance of immature neuron and, possibly, high intrinsic excitability of immature neurons (Ben-Ari 2002; Ben-Ari et al. 2007; Moody and Bosma 2005). Understanding how immature networks generate oscillations is conditionned by a detailled description of the developmental shifts of intrinsic and synapse driven properties and identification of the neuronal generators. Since the developing brain has a higher

\footnotetext{
Address for reprint requests and other correspondence: S. Rheims, Institut de Neurobiologie de la Mediterranee, INSERM U901, Université de la Méditerranée, Route de Luminy, Marseille, France (E-mail: sylvain.rheims@ free.fr).
}

incidence to seizures and synchronized activity patterns (BenAri 2006), this issue also directly related to epilepsies.

Like other brain regions, immature neocortical neurons generate oscillations that modulate the construction of functional maps (Cang et al. 2005; Kandler and Gillespie 2005; Katz and Shatz 1996; Khazipov et al. 2004b). These patterns are intrinsic since they occur in vitro (Aguilo et al. 1999; Corlew et al. 2004; Dupont et al. 2006; Garaschuk et al. 2000; Yuste et al. 1992) and are generated when neocortex is deprived of its sensory inputs (Hanganu et al. 2006; Khazipov et al. 2004b; Minlebaev et al. 2006). Although GABA depolarizes neocortical neurons (Daw et al. 2007b; Luhmann and Prince 1991; Owens et al. 1996, 1999; Yamada et al. 2004), cortical patterns reported to date (Aguilo et al. 1999; Corlew et al. 2004; Garaschuk et al. 2000; Yuste et al. 1992) are not generated by GABA (Garaschuk et al. 2000; McCabe et al. 2006). The reasons for this discrepancy and a possible contribution of intrinsic excitability properties of neurons (Burgard and Hablitz 1993; Daw et al. 2007b; Franceschetti et al. 1998; McCormick and Prince 1987; Picken Bahrey and Moody 2003; Reboreda et al. 2007; Zhang 2004; Zhou and Hablitz 1996) are yet unknown.

In this study, we describe the intrinsic and synapse driven properties of pyramidal neurons and interneurons in deep and superficial cortical layers during maturation and show that these properties underlie the generation of a layer specific pattern equivalent to the giant depolarizing potentials (GDPs) reported in many cortical and subcortical structures (Ben-Ari et al. 2007). We exclusively used the noninvasive techniques (single channel recordings) for measuring neuronal properties since, as we have shown previously (Tyzio et al. 2003), the invasive recording techniques (including perforated patch) result in significant errors in the estimation of $E_{\mathrm{m}}$ and $E_{\mathrm{GABA}}$ of immature neurons. We therefore used cell-attached recordings of N-methyl-D-aspartate (NMDA) and GABA channels to determine $E_{\mathrm{m}}$ and driving force of GABA $\left(D F_{\mathrm{GABA}}\right)$, respectively, and, importantly, measured both parameters in the same neuron thus identifying the genuine $E_{\mathrm{GABA}}$. We report the laminar and neuron type-specific distribution of excitatory action of GABA and intrinsic excitability that results in the generation of layer-specific network-driven oscillations. The impact of these properties on seizure generation is described in a companion paper (Rheims et al. 2008).

\footnotetext{
The costs of publication of this article were defrayed in part by the payment of page charges. The article must therefore be hereby marked "advertisement" in accordance with 18 U.S.C. Section 1734 solely to indicate this fact.
} 


\section{METHODS}

\section{Slices preparation}

Brain slices were prepared from postnatal day (P)1 to P15 Swiss mice of both sexes. P0 was the day of birth. All animal protocols conformed to the French Public Health Service policy and the INSERM guidelines on the use of laboratory animals. Animals were decapitated, and brains were removed. Sagittal slices $(300-400 \mu \mathrm{m})$ were cut using a Microm tissue slicer (International) with ice-cold oxygenated modified artificial cerebrospinal fluid (mACSF), with 0.5 $\mathrm{mM} \mathrm{CaCl} 2$ and $7 \mathrm{mM} \mathrm{MgSO}_{4}$, in which $\mathrm{Na}^{+}$was replaced by an equimolar concentration of choline. Slices were transferred into oxygenated normal ACSF containing (in $\mathrm{mM}$ ) $126 \mathrm{NaCl}, 3.5 \mathrm{KCl}, 1.2$ $\mathrm{NaH}_{2} \mathrm{PO}_{4}, 26 \mathrm{NaHCO}_{3}, 1.3 \mathrm{MgCl}_{2}, 2.0 \mathrm{CaCl}_{2}$, and 10 D-glucose, $\mathrm{pH}$ 7.4 , at room temperature $\left(20-22^{\circ} \mathrm{C}\right)$ for $\geq 1 \mathrm{~h}$ before use.

\section{Electrophysiology}

For recordings, slices were placed into a conventional fully submerged chamber superfused with ACSF $\left(32-34^{\circ} \mathrm{C}\right)$ at a rate of $2-3$ $\mathrm{ml} / \mathrm{min}$. Cell types were identified by IR-DIC video microscopy. Patch-clamp recordings were performed using dual EPC-9 or EPC-10 amplifiers (HEKA Elektronik). Pipettes (resistance of 3.5-8 MOhm) were pulled from borosilicate glass capillaries.

Patch-clamp recordings in cell-attached configuration were performed using the following pipette solutions (in $\mathrm{mM}$ ): for recordings of single GABA channels, $140 \mathrm{NaCl}, 2.5 \mathrm{KCl}, 2 \mathrm{CaCl}_{2}, 1 \mathrm{MgCl}_{2}, 10$ HEPES, and 0.01 GABA, pH adjusted to 7.3 by $\mathrm{NaOH}$; and for recordings of single NMDA channels: $140 \mathrm{NaCl}, 2.5 \mathrm{KCl}, 2 \mathrm{CaCl}_{2}, 10$ HEPES, 0.01 NMDA, 0.01 and glycine, $\mathrm{pH}$ adjusted to 7.3 by $\mathrm{NaOH}$. Analysis of currents through single channels and current-voltage relationships were performed using Clampfit 9.2 (Axon Instruments, Union City, CA) as described previously (Tyzio et al. 2003, 2006).

To estimate reliability of this technique for $E_{\mathrm{m}}$ measurements, we performed an experiment using dissociated cultures of rat hippocampus at 16-21 days in vitro. We first estimated $E_{\mathrm{m}}$ in the intact cell using cell-attached recordings of NMDA channels that gave a value of $-81 \pm 3 \mathrm{mV}(n=3$ for dual recordings; $n=8$ for single cellattached recordings). Keeping cell-attached recordings, the cell was patched with a second pipette and recorded in the whole cell mode. Under these recording conditions, $E_{\mathrm{m}}$ deduced from cell-attached recordings of NMDA channels shifted to a more depolarized value of $-54 \pm 4 \mathrm{mV}(n=3)$ that was close to the $E_{\mathrm{m}}$ measured directly in whole cell recordings $(-56 \pm 3 \mathrm{mV} ; n=72)$, and the difference between these two values was within $\pm 3 \mathrm{mV}(0.9 \pm 1.3 \mathrm{mV} ; n=3)$ (Tyzio et al. 2008).

In addition, because the composition of solution for cell-attached recordings differs from ACSF, it may introduce a systematic error in measurements of $D F_{\mathrm{GABA}}$. This error was estimated experimentally in two experimental sets. First, we determined the reversal potential of currents via GABA channels in outside-out patches. To prevent rundown of GABA currents, $2 \mathrm{mM} \mathrm{Mg-ATP}$ and $5 \mathrm{mM}$ EGTA were added to the pipette solution. Brief pressure application of isoguvacine (100 $\mu \mathrm{M}, 100 \mathrm{~ms}, 2-8 \mathrm{psi}$ ) to the outside-out or nucleated patches evoked $\mathrm{GABA}_{\mathrm{A}}$ receptor $\left(\mathrm{GABA}_{\mathrm{A}} \mathrm{R}\right)$-mediated currents that were completely suppressed by the $\mathrm{GABA}_{\mathrm{A}} \mathrm{R}$ antagonist bicuculline (20 $\mu \mathrm{M} ; n=2$, data not shown). Current-voltage relationships showed that these responses have a reversal potential of $2.1 \pm 0.4 \mathrm{mV}(n=$ 7 for outside-out and $n=1$ for nucleated patches). In a second series of experiments, we measured $D F_{\mathrm{GABA}}$ in cell-attached configuration (1-month-old rats) using the pipette solution containing ACSF and GABA $(2 \mu \mathrm{M})$. To maintain $\mathrm{pH}$ at a physiological level, the pipette ACSF was continuously oxygenated with $95 \% \mathrm{O}_{2}-5 \% \mathrm{CO}_{2}$ via the patch pipette holder. The value of $D F_{\mathrm{GABA}}$ with the ACSF-based pipette solution was of $4.0 \pm 0.6 \mathrm{mV}(n=9)$ compared with $5.4 \pm$ $1.3 \mathrm{mV}(n=4)$ obtained using the pipette solution for GABA channel recordings. The difference of $1.6 \mathrm{mV}$ was close to that obtained with outside-out patches (2.1 mV) (Tyzio et al. 2008).

Analyzing GABA-activated single channel recordings, we used a linear fit since a function theoretically appropriate for fitting currentvoltage relationships is not known. We compared reversal potentials obtained with the linear or polynomial fit in 14 randomly selected cells (P2-P15). With the linear fit, $D F_{\mathrm{GABA}}$ was more depolarizing by $0.6 \pm 0.78 \mathrm{mV}$.

Patch-clamp recordings in the whole cell configuration were performed using the following pipette solution (in $\mathrm{mM}$ ): 115 potassium gluconate, $20 \mathrm{KCl}, 4$ ATP-Mg, $10 \mathrm{Na}$-phosphocreatine, $0.3 \mathrm{GTP}-\mathrm{Na}$, 10 HEPES, and $0.5 \%$ biocytin, $\mathrm{pH} 7.3$, adjusted by $\mathrm{NaOH}$. A similar solution was used for recordings of action potentials (APs).

Field potentials were recorded using electrodes made from borosilicate glass capillaries filled with ACSF. Signals were amplified using DAM8A (World Precision Instruments).

Continuous recordings were digitized $(10 \mathrm{kHz})$ on-line using a Digidata 1322 (Axon Instruments) and analyzed off-line with Clamfit 9.0 (Axon Instruments). Noncontinuous recordings were digitized (10 or $50 \mathrm{KHz}$ ) on-line and analyzed off-line (Igor Wavemetrics, Lake Oswego, OR).

\section{Measurements of $V_{\text {thr }}$}

Cells were excited by random synaptic stimulation (L2/3 and L4) or spontaneous oscillations (L5/6). During random synaptic stimulation, nerve fibers were stimulated each $10 \mathrm{~s}$ via a bipolar metal extracellular electrode $(50 \mu \mathrm{m})$ positioned in L1, L4, or white matter. Each stimulus consisted of a random sequence of 0.2 -ms stimuli (minimal interpulse interval, $10 \mathrm{~ms}$ ) for $200 \mathrm{~ms}$. Detection of the AP activation threshold was performed off-line using the custom made software (IGOR Pro, WaveMetrics). Only the first AP in each sequence was analyzed. $V_{\text {thr }}$ was detected by measuring the maximum of a second derivative of membrane potential. The average potential slope was measured by averaging the first derivative of membrane potential in the time range starting from the set deviation from $E_{\mathrm{m}}$ and up to $V_{\mathrm{thr}}$.

Since the input resistance of neurons was large [522 \pm 159 (SD) $\mathrm{M} \Omega$ for L2/3 pyramids; $734 \pm 324 \mathrm{M} \Omega$ for L2/3 interneurons; $560 \pm$ $96 \mathrm{M} \Omega$ for L4 stellate cells; $430 \pm 149 \mathrm{M} \Omega$ for L5/6 pyramids; $491 \pm$ $128 \mathrm{M} \Omega$ for L5/6 interneurons at P7-P8], it was necessary to correct the measured potentials (Tyzio et al. 2003) using the following formula

$$
V=V^{*} \times R_{\text {seal }} /\left(R_{\text {seal }}-R_{\text {in }}\right)
$$

where $V^{*}$ is the measured potential; $R_{\text {seal }}$ is the seal resistance; and $R_{\text {in }}$ is the input resistance.

\section{Pharmacology}

Drugs used were purchased from Tocris (gabazine, NBQX, D-APV), Sigma (bumetanide, biocytin, picrotoxin), and Roche Pharmaceutical Division (diazepam).

\section{Histological processing}

To show biocytin-injected cells, slices were immerged in a fixative solution of paraformaldehyde $(4 \%)$ and glutaraldehyde $(0.2 \%)$ overnight at $4{ }^{\circ} \mathrm{C}$ after electrophysiological recordings. To increase penetration of the reagents used for biocytin detection, slices were quickly frozen on dry ice and thawed in a phosphate buffer. Slices were rinsed in $0.05 \mathrm{M}$ Tris-buffered saline (TBS), $\mathrm{pH} 7.4$, containing $0.3 \%$ Triton $\mathrm{X}-100$ for $30 \mathrm{~min}$ and incubated overnight at $4^{\circ} \mathrm{C}$ in an avidin-biotinperoxidase solution prepared in TBS according to the manufacturer recommendation (Vectastain Elite ABC, Vector Laboratories, Burlingame, CA). After a 30-min wash in TBS and a 10-min rinse in Tris buffer (TB), $\mathrm{pH} 7.6$, slices were processed for $15 \mathrm{~min}$ in $0.06 \%$ 
3-3-diaminobenzidine tetrahydrochloride and $0.01 \%$ hydrogen peroxide diluted in TB. The slices were rinsed in TB for $30 \mathrm{~min}$, mounted on gelatin-coated slides, dehydrated, and coverslipped with permount. Stained cells were reconstructed for morphometric analysis using the Neurolucida system (MicroBrightField, Colchester, VT).

\section{Statistical analysis}

Group measures are expressed as means $\pm \mathrm{SE}$; error bars also indicate SE. The statistical significance was assessed with the Student's $t$-test or ANOVA. The level of significance was set at $P<0.05$.

\section{RES ULTS}

\section{Strongly depolarizing GABA signaling over the first postnatal week}

To determine the effects of GABA, it is essential to measure correctly the basic electrical properties of immature neurons, in particular, $E_{\mathrm{m}}$ and $E_{\mathrm{GABA}}$. We relied exclusively on noninvasive recordings and measured $E_{\mathrm{m}}$ and $E_{\mathrm{GABA}}$ in the same target neurons by analyzing $I-V$ relations for NMDA- and GABAactivated single channels with a dual patch recording protocol (Fig. 1A). Recordings in the same neuron enabled measuring both values in absolute potentials. At P7-P8 (Fig. $1 B$ ), $E_{\mathrm{m}}$ of neurons in L2/3 and L4 was not statistically different $(P=0.38$ by ANOVA) for L2/3 pyramidal cells $(-84.5 \pm 1.2 \mathrm{mV} ; n=$ $35)$, for $\mathrm{L} 2 / 3$ interneurons $(-82 \pm 1.5 \mathrm{mV} ; n=18)$, and for L4 spiny stellate cells $(-82 \pm 1 \mathrm{mV} ; n=13)$. In contrast, $E_{\mathrm{m}}$ of both pyramidal and interneurons of L5/6 were significantly more depolarized than $\mathrm{L} 2 / 3$ neurons $[-73.9 \pm 0.7 \mathrm{mV}(n=$ 23 ) for pyramidal cells; and $-69.2 \pm 3 \mathrm{mV}$ for interneurons $(n=9), P<0.001$ by ANOVA]. Therefore deep layer neurons have $\sim 10 \mathrm{mV}$ more depolarized $E_{\mathrm{m}}$ than superficial layer neurons and are potentially more liable for excitation.

Figure $1 C$ shows $E_{\mathrm{GABA}}$ values in different cell types and layers at P7-P8. The mean $E_{\mathrm{GABA}}$ values were $-53.8 \pm 2 \mathrm{mV}$ for L2/3 pyramidal cells $(n=10) ;-47.5 \pm 2.1 \mathrm{mV}$ for $\mathrm{L} 2 / 3$ interneurons $(n=9) ;-52.7 \pm 3.3 \mathrm{mV}$ for L4 stellate cells $(n=13) ;-49.6 \pm 2.1 \mathrm{mV}$ for L5/6 pyramidal cells $(n=18)$; and $-46.5 \pm 2 \mathrm{mV}$ for L5/6 interneurons $(n=9)$. $E_{\mathrm{GABA}}$ values deviated in cells of the same type, presumably reflecting variability of $\left[\mathrm{Cl}^{-}\right]_{\mathrm{i}}$. Nevertheless, a considerable difference in the $E_{\mathrm{GABA}}$ and $E_{\mathrm{m}}$ values (Fig. $1 D$ ) allows to conclude that, for all layers and cell types, GABAergic transmission provide a strong depolarizing drive.

Figure $2 A$ shows the developmental profile of $E_{\mathrm{m}}$ and $E_{\mathrm{GABA}}$ in pyramidal cells of L2/3 and L5/6. The profiles suggest that a switch of GABA actions occurs after P10. Before this age, $E_{\mathrm{GABA}}$ gradually increases in all layers. Interestingly, $E_{\mathrm{m}}$ gradually hyperpolarizes with age reaching a steady-state level after P5 $\left(P<0.001\right.$ by ANOVA for $E_{\mathrm{m}}$ at $<$ P5 and $>$ P5 for both L2/3 and L5/6 pyramidal cells). $E_{\mathrm{m}}$ of pyramidal cells in L2/3 and L5/6 do not differ significantly at P9-P14 [-80.4 \pm $1.1 \mathrm{mV}(n=31)$ and $-78.7 \pm 1.4(n=25)$, respectively; $P=$ 0.34 , by ANOVA].

To verify that the positive values of $E_{\mathrm{GABA}}$ are related to a high $\left[\mathrm{Cl}^{-}\right]_{\mathrm{i}}$, we blocked activity of the NKCC1 transporter by $10 \mu \mathrm{M}$ bumetanide (Yamada et al. 2004). Single channel $I-V$ relations were measured in control and after application of bumetanide in the same L5/6 pyramidal cells (Fig. 2B). At P7-P8, bumetanide induced a small but significant hyperpo- larization $\left(E_{\mathrm{m}}=-73.9 \pm 1 \mathrm{mV}\right.$ in control and $-78.6 \pm 1.3$ $\mathrm{mV}$ after bumetanide; $n=15 ; P<0.01$, paired $t$-test). Bumetanide also induced a strong reduction in $\left[\mathrm{Cl}^{-}\right]_{\mathrm{i}}$ and corresponding $E_{\mathrm{GABA}}\left(E_{\mathrm{GABA}}=-52.8 \pm 3.5 \mathrm{mV}\right.$ in control and $-76.4 \pm 3.5 \mathrm{mV}$ after bumetanide; $n=6 ; P<0.01$, paired $t$-test). Interestingly, the effect of bumetanide on $E_{\mathrm{m}}$ was more pronounced at P4 (Fig. $2 B$ ): $-68.2 \pm 2 \mathrm{mV}$ in control and $-78.7 \pm 3.2 \mathrm{mV}$ after bumetanide $(n=7)$. In presence of bumetanide, the $E_{\mathrm{m}}$ values did not differ significantly at P4 and P7-P8 $(P=0.97)$, suggesting that the age-dependent $E_{\mathrm{m}}$ depolarization directly relates to $\left[\mathrm{Cl}^{-}\right]_{\mathrm{i}}$. The mechanism underlying this effect was not investigated further.

\section{Layer 5/6 pyramidal neurons have a more negative action potential threshold than L2/3 pyramidal neurons}

Another major factor that underlies neuronal excitability is the AP threshold $\left(V_{\mathrm{thr}}\right)$. Since $V_{\mathrm{thr}}$ is defined by co-activation of voltage-sensitive channels during synaptic input, we measured $V_{\text {thr }}$ in spontaneously generated APs or in APs induced by random extracellular synaptic stimulation (see METHODS).

Figure $3 A$ shows the dependence of $V_{\text {thr }}$ on the average potential slope in APs induced in three L2/3 interneurons (P7-P8) by random synaptic stimulation (see inset). All interneurons (coded by different colors) were filled out with biocytin and reconstructed afterward. Representative reconstructions of interneurons are shown in Fig. 3A. Scattering of the $V_{\mathrm{thr}}$ values reflects the heterogeneity of interneuron population. The mean $V_{\text {thr }}$ was $-47.6 \pm 4 \mathrm{mV}(n=9)$. Note, however, that some interneurons subtypes (e.g., in blue on Fig. $3 A$ ) have a $V_{\text {thr }}$ at about $-60 \mathrm{mV}$, indicating that the corresponding interneurons are highly excitable. Measurements in L5/6 interneurons (Fig. 3B) also showed pronounced variability of the $V_{\text {thr }}$ values and corresponding heterogeneity of interneuron subtypes. Primary morphological characterization of interneurons is provided in Supplementary Materials. ${ }^{1}$

Similar measurements in L2/3 pyramidal and L4 stellate cells at P7-P8 showed much smaller variability of the $V_{\text {thr }}$ values within each neuron type (Fig. $3 C$ ). The mean $V_{\text {thr }}$ values were $-36.8 \pm 0.46 \mathrm{mV}$ at neocortical pyramids (12 cells) and $-37.4 \pm 0.4 \mathrm{mV}$ at stellate cells (11 cells). Thus $V_{\mathrm{thr}}$ in both neuron types are very positive, indicating that voltage deviations from $E_{\mathrm{m}}$ of $>40 \mathrm{mV}$ are required for activating these neurons (Fig. 3D). L5/6 pyramidal cells at P7-P8 had more negative $V_{\text {thr }}(P<0.001$ for L2/3 and L5/6 pyramids), $-42 \pm$ $1.9 \mathrm{mV}$ (16 cells), with large variability between neurons (Fig. $3 C$ ). Importantly, plotting the mean $V_{\mathrm{thr}}$ values relative to the corresponding mean $\mathrm{E}_{\mathrm{m}}$ values (Fig. $3 D$ ) clearly shows that L5/6 neurons are potentially more excitable than neurons in other layers. For pyramidal cells, this conclusion remains valid at $\mathrm{P} 14$ animals (Fig. 3, $E$ and $F$ ), although $V_{\text {thr }}$ is getting significantly more negative for both L2/3 $(-48.3 \pm 1.2 \mathrm{mV}$, $P<0.001)$ and L5/6 $(-54.7 \pm 3.7 \mathrm{mV}, P<0.001)$ pyramids. Neuron spiking could be induced by synaptic stimulation at earlier ( $<$ P5) ages. Unfortunately, a very high membrane resistance $(>1 \mathrm{GOhm})$ of neurons prevented the accurate estimation of $V_{\text {thr }}$ at these ages.

Therefore deep layer pyramidal neurons are more excitable than superficial ones because of a lower $V_{\mathrm{thr}}$.

\footnotetext{
${ }^{1}$ The online version of this article contains supplemental data.
} 
A P2, Cortical plate pyramid
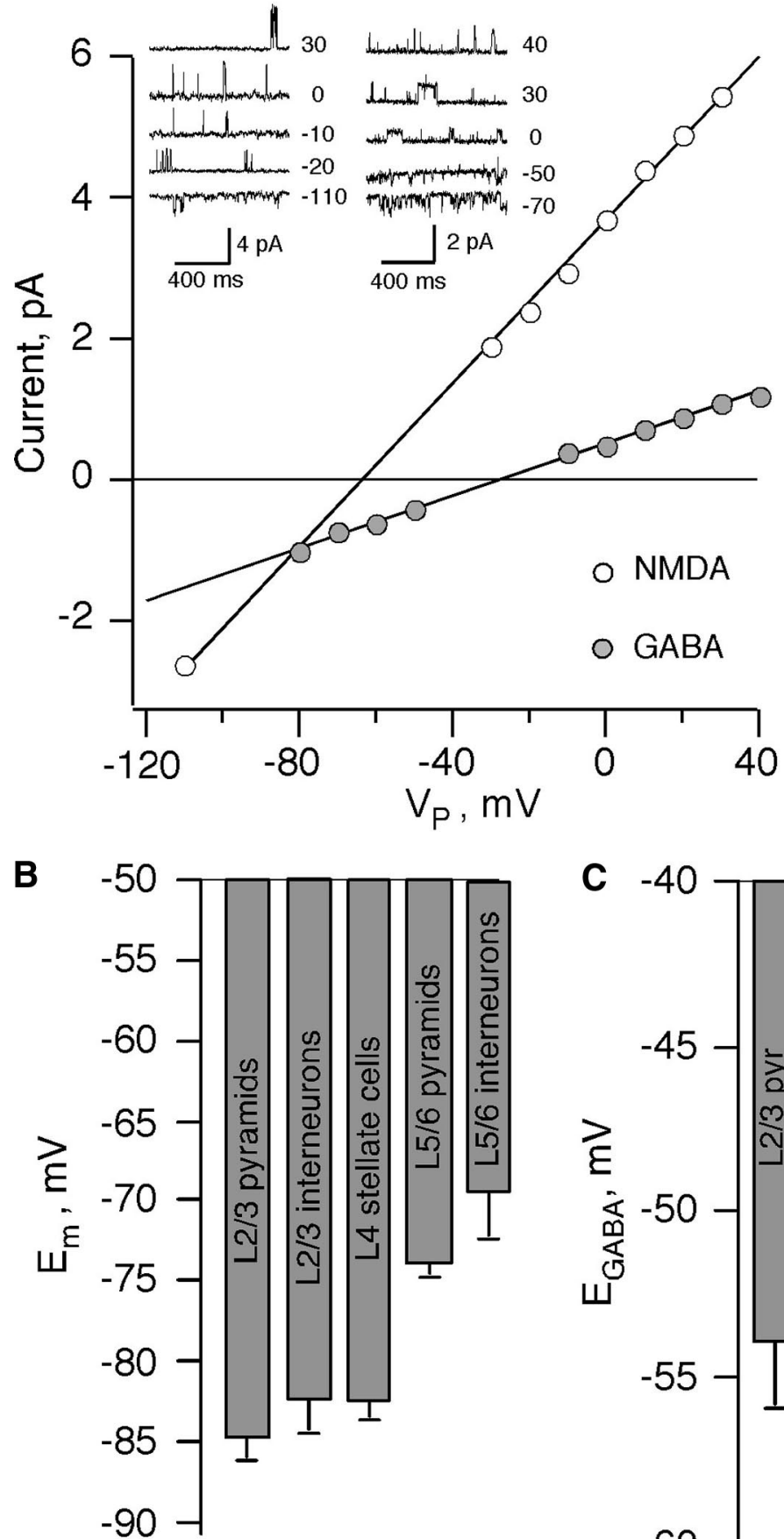

P9, L2/3 pyramid

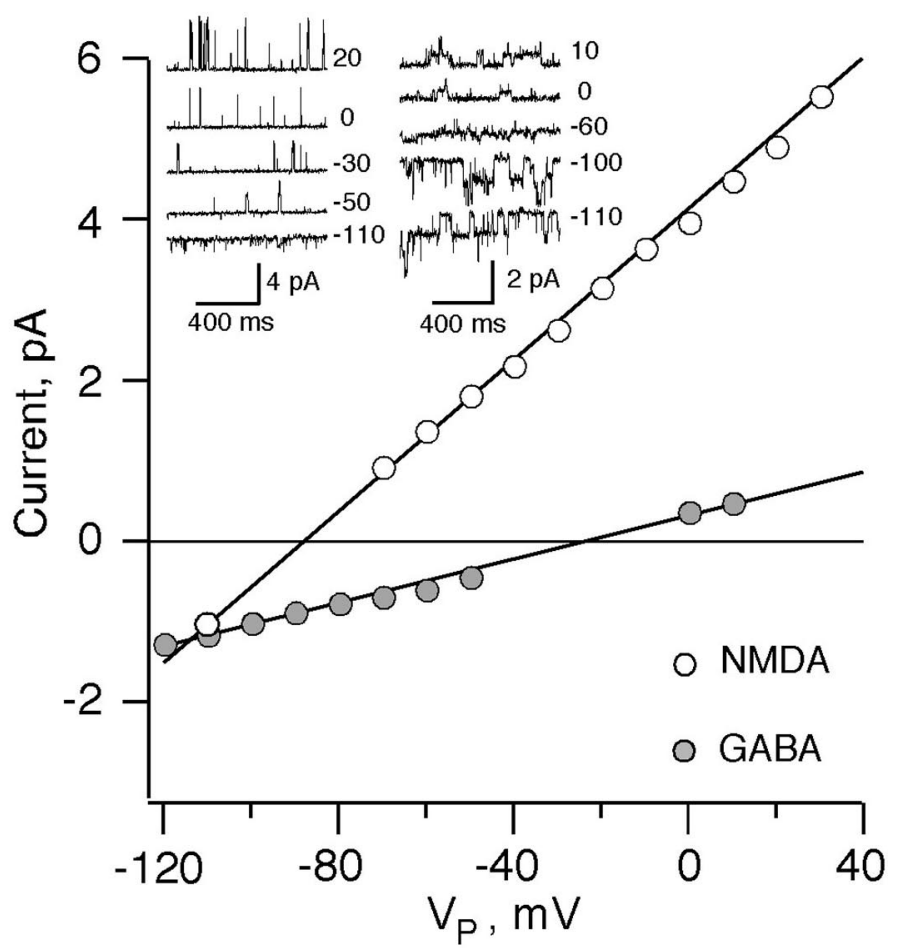

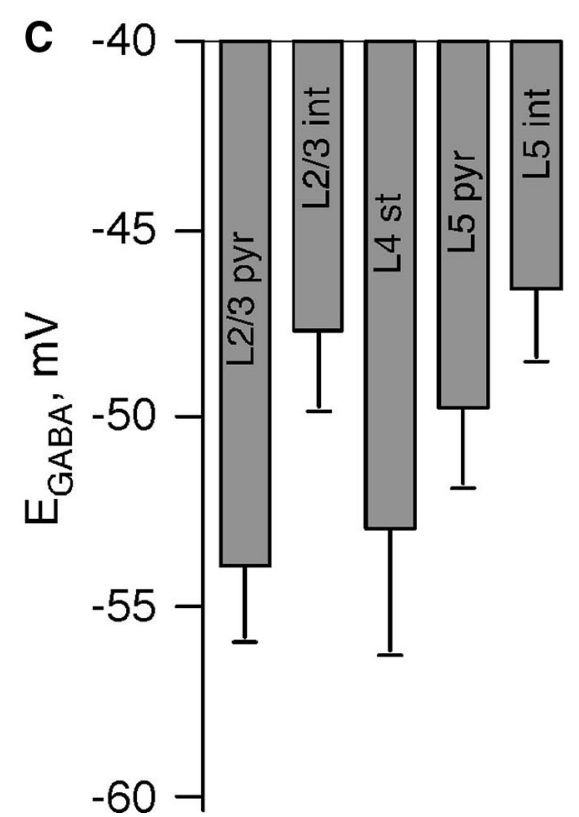

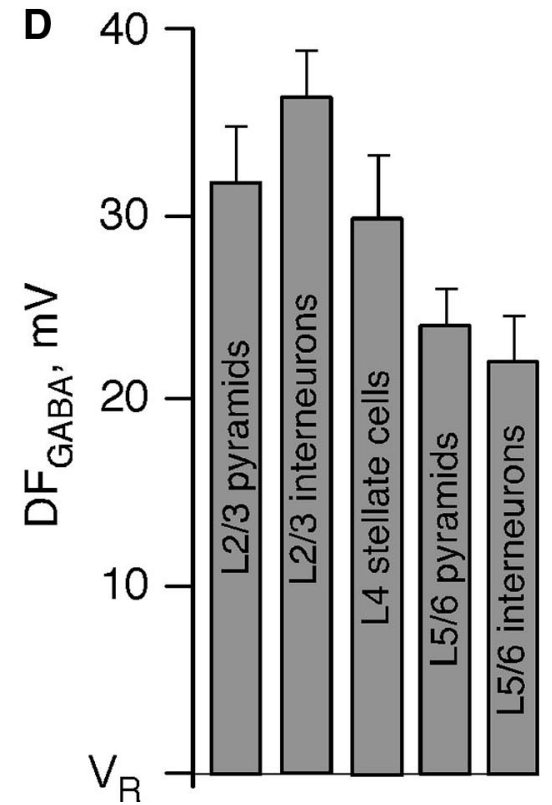

FIG. 1. $E_{\mathrm{m}}$ and $E_{\mathrm{GABA}}$ in neonatal neurons measured by cell-attached recordings of single $N$-methyl-D-aspartate (NMDA)- and GABA-activated channels. $A$ : current-voltage relationships of single NMDA- and GABA-activated channels. Inset: examples of single NMDA (left) and GABA (right) channel activity at various pipette potentials. Recordings from the same P2 cortical plate pyramidal cell (left) and from the same P9 layer 2/3 pyramidal cell (right). B: $E_{\mathrm{m}}$ in various cell types and layers of mouse P7-P8 neocortical slices (97 neurons). $C$ : values of $E_{\mathrm{GABA}} . D$ : GABA driving force $\left(D F_{\mathrm{GABA}}\right)$ in different cell types and layers of mouse neocortical slices at P7-P8 (59 neurons).

GABAergic transmission generates APs in L5/6 but not L2/3 pyramidal neurons

The results above suggest that, at P7-P8, GABAergic transmission is depolarizing and presumably strong enough to initiate cell firing. To directly test this hypothesis, we blocked glutamatergic transmission ( $5 \mu \mathrm{M}$ NBQX $+50 \mu \mathrm{M}$ APV) and stimulated slice by the extracellular electrode (Davies et al. 1990). In most interneurons tested in L2/3 (10 of 11), extra- cellular stimulation induced APs (Fig. 4A, cell-attached recordings). This was prevented by application of $10 \mu \mathrm{M}$ gabazine (data not shown). In contrast, such stimulation failed to induce APs in L2/3 pyramidal cells ( $n=5$; Fig. $4 A$ ). In L5/6, extracellular stimulation reliably induced APs in both pyramidal cells and interneurons (Fig. 4A). Figure $4 B$ represents a summary of these experiments, and Fig. $4 C$ shows deviations between the mean values of $E_{\mathrm{GABA}}$ and $V_{\mathrm{thr}}$ in each cell type. 
A

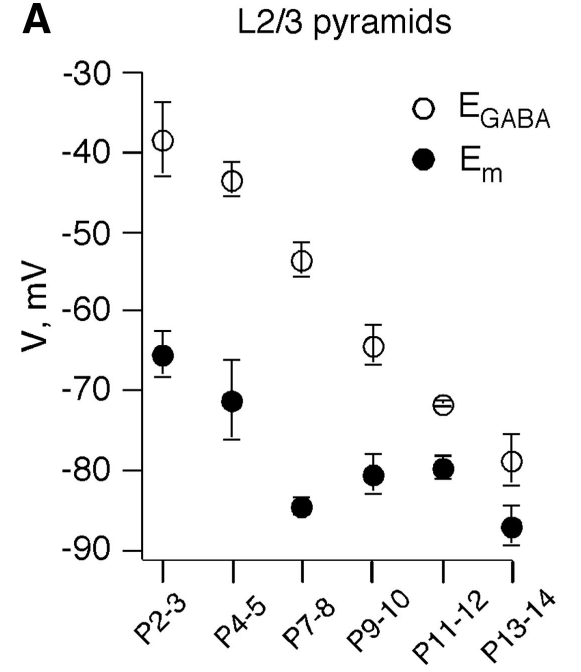

L5/6 pyramids

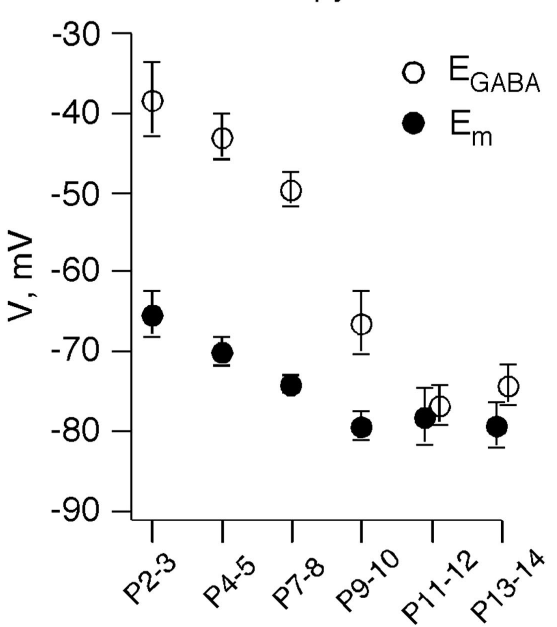

B

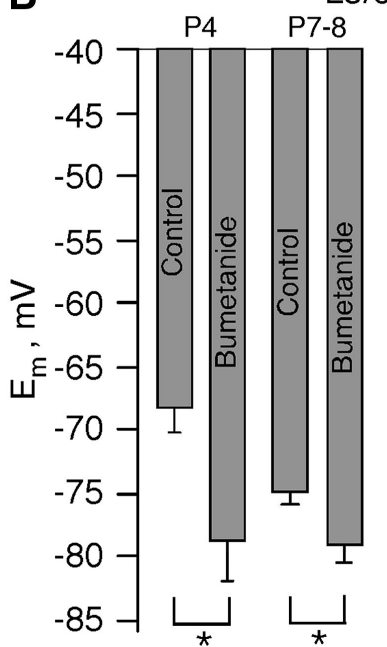

L5/6 pyramids

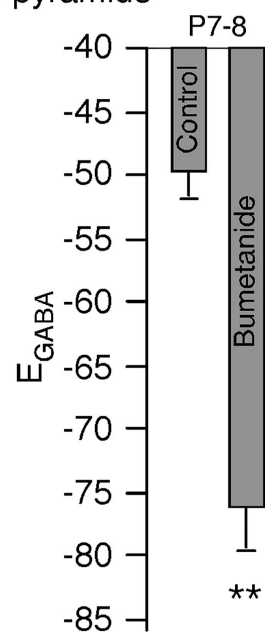

FIG. 2. Developmental profile of $E_{\mathrm{m}}$ and $E_{\mathrm{GABA}}$ in pyramidal cells. $A$ : developmental changes in $E_{\mathrm{m}}$ and $E_{\mathrm{GABA}}$ in layer $2 / 3$ and $5 / 6$ pyramidal cells (pooled data from 166 cells). $B$ : bumetanide, a NKCC1 chloride co-transporter antagonist, induces hyperpolarization of $E_{\mathrm{m}}$ in P4 (7 cells) and P7/8 layer 5/6 pyramidal cells ( 15 cells) and strongly decreases $E_{\mathrm{GABA}}$ in $\mathrm{P} 7 / 8$ layer 5/6 pyramidal cells (6 cells).

Note, that APs are generated in a fraction of L5/6 neurons, although their mean $E_{\mathrm{GABA}}$ is more negative than mean $V_{\mathrm{thr}}$. This can be explained by the large deviations of $V_{\mathrm{thr}}$ in neuron populations (from -35 to $-60 \mathrm{mV}$ for interneurons and from -31 to $-58 \mathrm{mV}$ for pyramids). It is also because of the activation of $\mathrm{Na}$ channels that boost postsynaptic potentials (PSPs), thereby facilitating the generation of APs (Häusser et al. 2001; Williams and Stuart 2003). Indeed, Fig. 4D shows whole cell recordings in an L2/3 pyramidal cell and an interneuron. The pipette solution contained $20 \mathrm{mM} \mathrm{Cl}^{-}$that corresponded to an $E_{\mathrm{GABA}}$ of about $-49 \mathrm{mV}$ (shown by dash lines on the figure). Nevertheless, GABAergic PSP values recorded at the soma exceeded $E_{\mathrm{GABA}}$ and readily triggered APs.

Thus GABAergic synapses are able to initiate APs in the intact L2/3 interneurons but not in pyramidal cells. L5/6 pyramidal cells seem to be more excitable than the L2/3 ones since they have been readily activated by GABAergic transmission.

\section{Recurrent GABA driven oscillations in deep layer neurons}

At P6-P8, field and cell-attached recordings showed recurrent oscillations (each $20 \mathrm{~s}$ in average; $<1$-s duration) in the majority of slices (68/76; see Fig. $5 A$ ). These oscillations are generated by deep layer (L5/6) neurons since 1) simultaneous field recordings show that they are most powerful in L5/6, much smaller in L4 and nearly absent in L2/3 (Fig. 5B); (4 similar experiments; 13 experiments with simultaneous L2/3 and L5/6 recordings); 2) combined field and dual cell-attached recordings showed that pyramidal cells and interneurons of L2/3 are quiescent during oscillations (Fig. 5, $C$ and $D ; 12 / 14$ interneurons were silent and 21/21 pyramids); field oscillations in L4 are not associated with firing of stellate or pyramidal cells (Fig. 5, $C$ and $D ; 7$ cells); oscillations are always synchronous with firing of most pyramidal cells and interneurons in L5/6 (Fig. 5, $A$ and $D ; 23$ pyramidal cells and 23 interneurons); 3) oscillations always sustain after resection of all subcortical regions ( $n=4$; not shown); and 4) a mini-slice, prepared from a L5/6 slice region originally showing oscillations (Supplementary Fig. S2), is still highly active (6 similar experiments). In contrast, surgically isolated superficial layers did not show any activity (3 experiments; data not shown). These results are summarized in Fig. 5D. Therefore the dominant activity pattern at that developmental stage is generated by deep cortical layer neurons.

The following observations suggest that these oscillations, referenced as cortical GDPs (cGDPs), resemble the classical GDPs recorded in hippocampus and other developing brain structures (Ben-Ari et al. 1989; for review, see Ben-Ari 2002; Feller 1999). First the oscillations are controlled by GABAergic signaling: 1) the cGDP frequency is significantly reduced by low doses of gabazine (100 $\mathrm{nM}, n=3$; Fig. $6, A$ and $B)$, a selective $\mathrm{GABA}_{\mathrm{A}} \mathrm{R}$ antagonist; and by low doses of picrotoxin ( $3 \mu \mathrm{M}, n=4$; Fig. $6 B$ ), a specific GABA channel blocker; 2) the cGDP frequency is highly increased by diazepam ( $5 \mu \mathrm{M}, n=3$; Fig. 6, $A$ and $B$ ), a benzodiazepine efficiently enhancing GABAergic currents; and 3) bumetanide $(10 \mu \mathrm{M}$, $n=9$; Fig. 6, $A$ and $B$ ), which reduces the intracellular concentration of chloride $\left(\left[\mathrm{Cl}^{-}\right]_{\mathrm{i}}\right)$ by blocking activity of NKCC1 (Dzhala et al. 2005; Hannaert et al. 2002; Yamada et al. 2004), significantly suppresses cGDPs. Second, cGDPs require operative glutamatergic synapses since they are suppressed by APV ( $50 \mu \mathrm{M}, n=3$; Fig. $6 B)$ and abolished by NBQX (5 $\mu \mathrm{M}, n=2$; Fig. $6 B)$. Third, like GDPs of the hippocampus (Ben-Ari et al. 1989; Khazipov et al. 2004a), cGDPs are present only transiently during maturation. As shown in Fig. $6 C$, the peak occurrence of cGDPs is within P6-P10 and they disappear by the end of second postnatal week.

To ensure that the network oscillations are not animal strain specific, we also tested the presence of cGDPs in P5-P8 rat slices and observed oscillations in all experiments $(n=7)$. Therefore cGDPs are generated by a mutual excitatory activity of pyramidal cells and interneurons in deep cortical layers.

\section{I S C U S S I O N}

Using noninvasive single channel recordings, we showed that GABA robustly depolarizes immature neocortical neurons. However, although strong GABAergic depolarizing drive was 


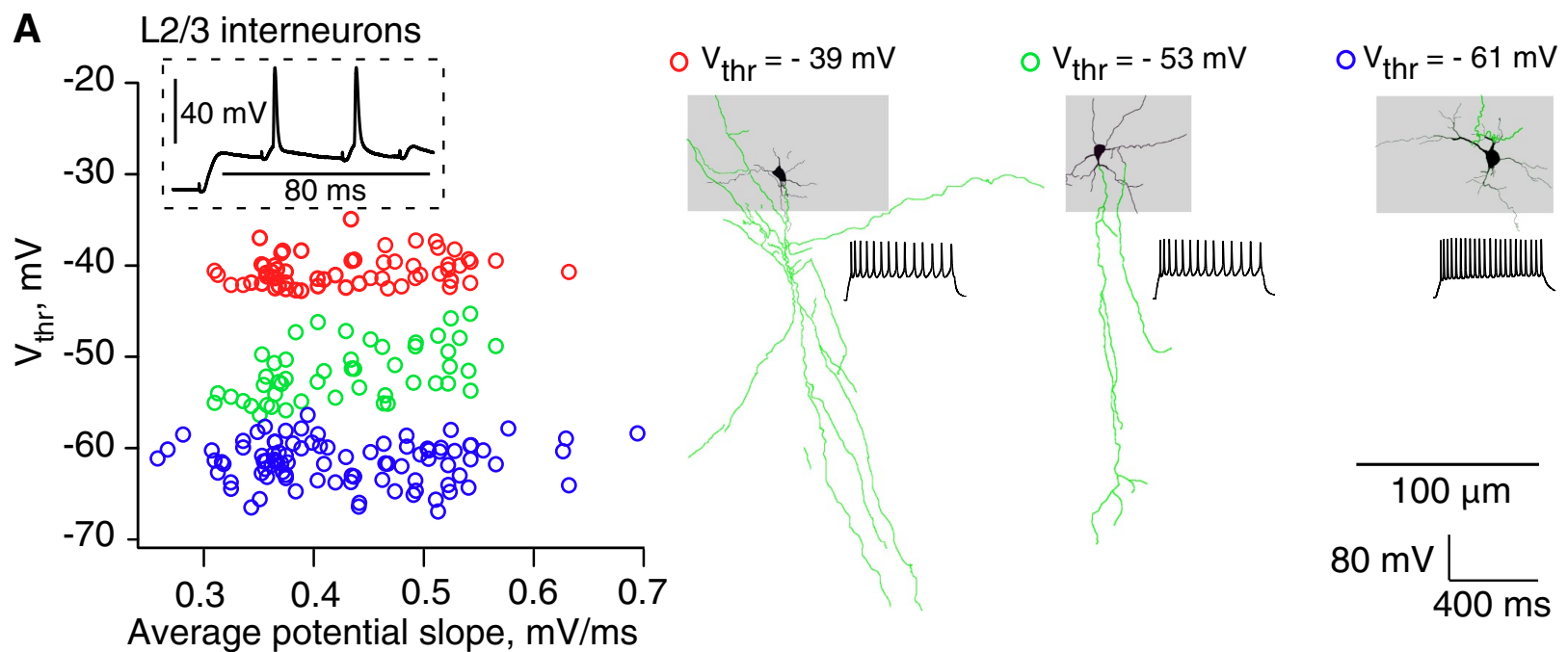

B L5/6 interneurons

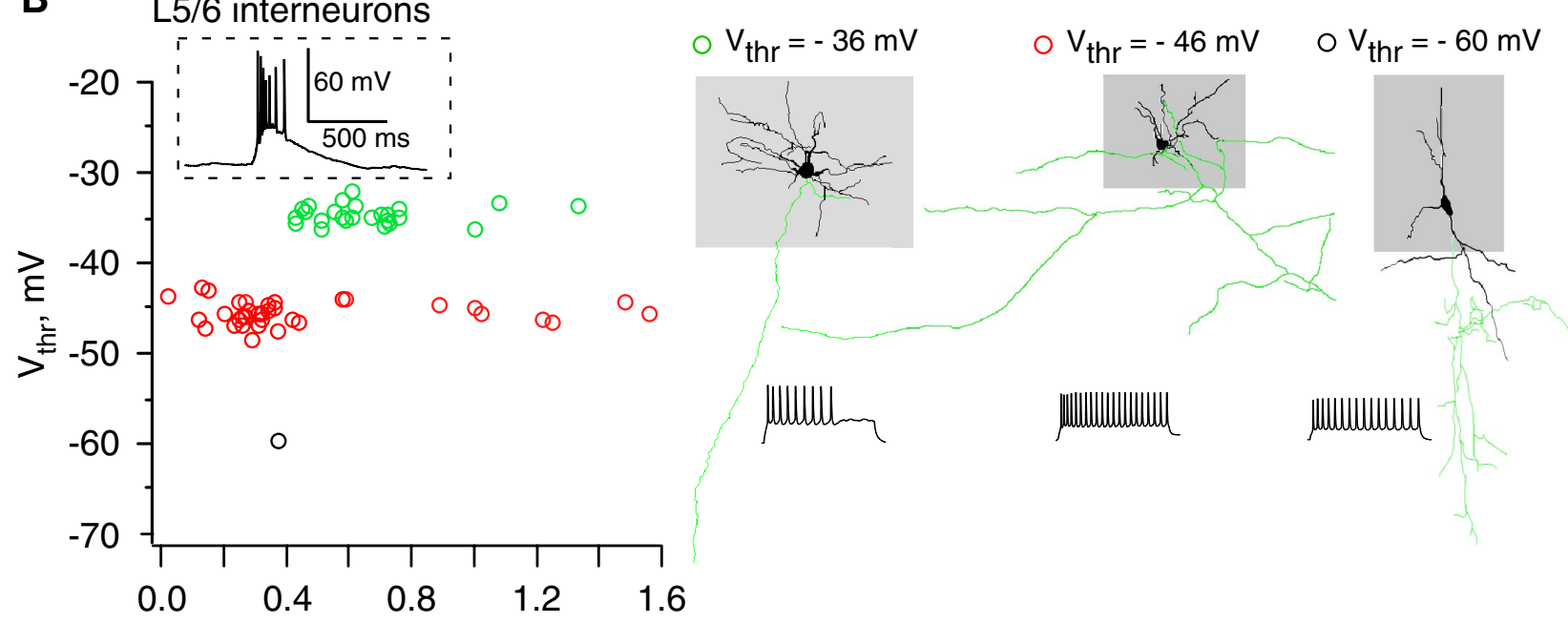

Average potential slope, $\mathrm{mV} / \mathrm{ms}$
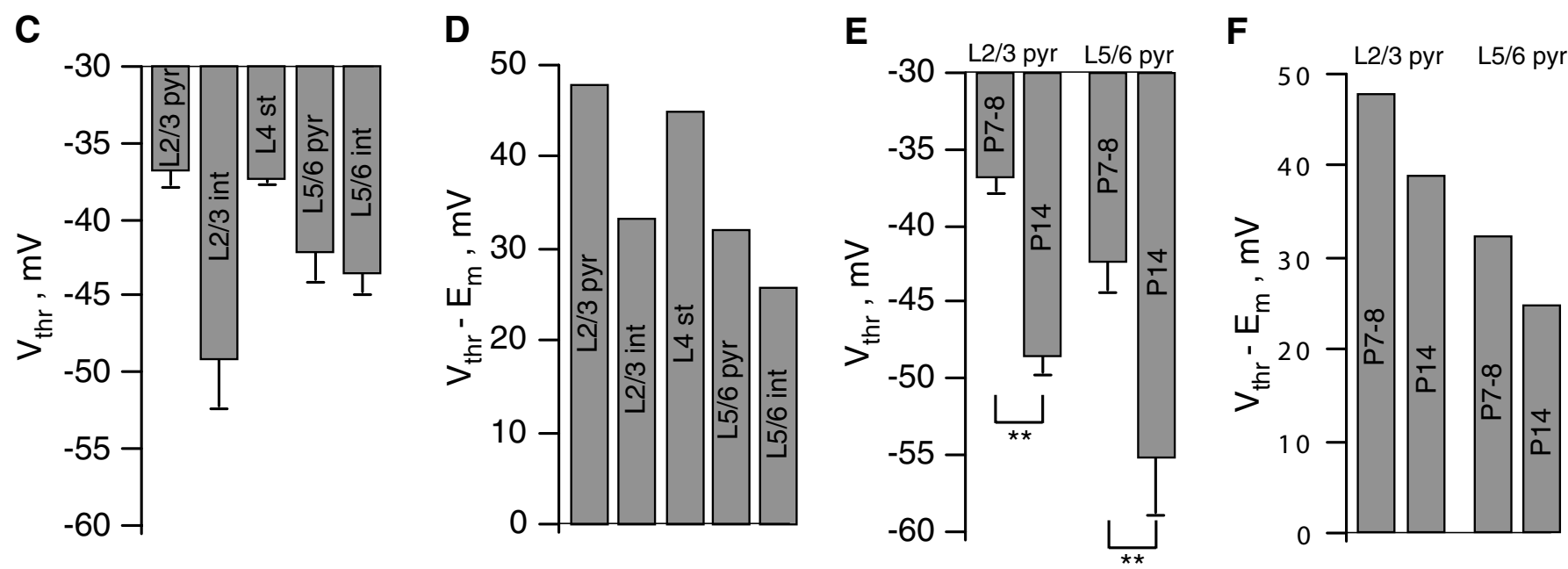

FIG. 3. Action potential threshold ( $\left.V_{\mathrm{thr}}\right)$ of neonatal neurons. Measurements of $V_{\text {thr }}$ in $(A)$ L2/3 and $(B)$ L5/6 interneurons. Cells were excited by random synaptic stimulation (L2/3) or spontaneous oscillations (L5/6). Color codes correspond to the interneurons labeled with biocytin and shown on the right panels. $C: V_{\text {thr }}$ in various cell types of P7-P8 neocortex (63 neurons). $D$ : difference between $E_{\mathrm{m}}$ and $V_{\mathrm{thr}}$ (relative threshold) in different cell types of P7-P8 neocortex. $E$ : developmental changes in $V_{\mathrm{thr}} . F$ : the relative threshold in layer $2 / 3$ and $5 / 6$ pyramidal cells (37 neurons). 
A

P7 NBQX + APV

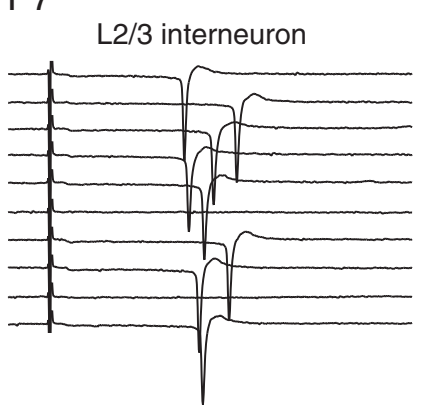

L2/3 pyramidal

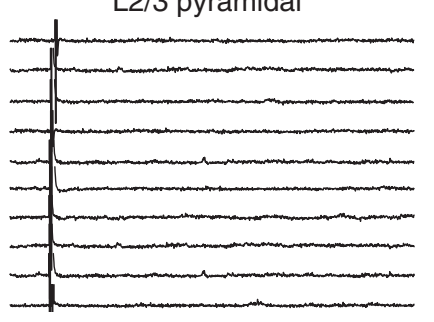

B
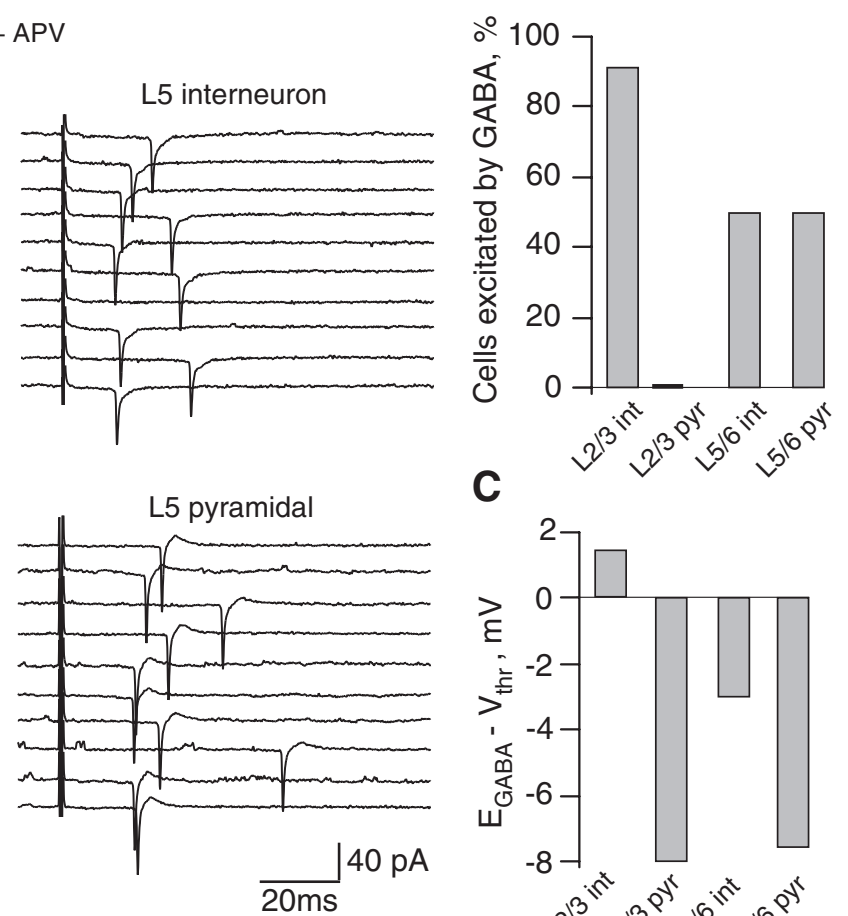

L5 interneuron

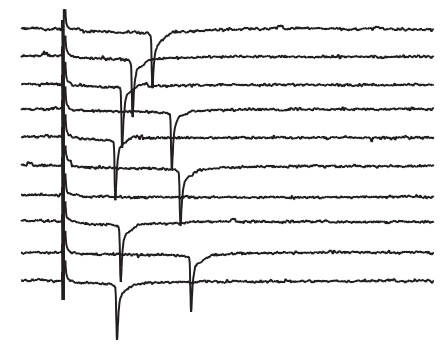

C

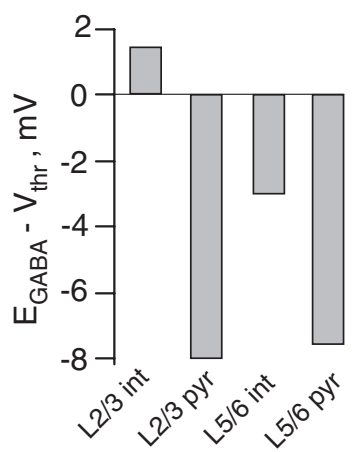

D

L2/3 pyramidal cell

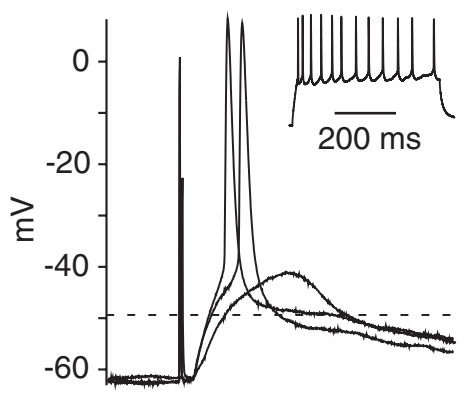

L2/3 interneuron

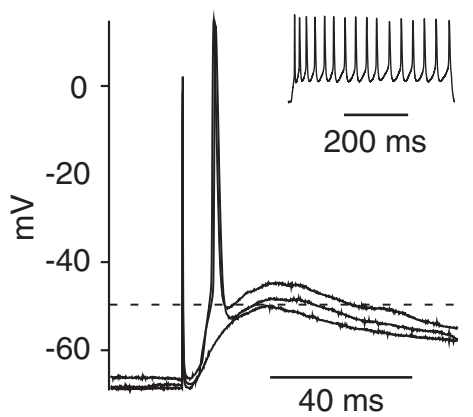

FIG. 4. Cell type and layer specificity of the excitatory GABA action in the immature neocortex. $A$ : examples of responses to synaptic activation of GABA receptors $\left(\mathrm{GABA}_{\mathrm{A}} \mathrm{Rs}\right.$; stimulation in the presence of NBQX and APV) in different cell types recorded in a cell-attached mode. $B$ : summary plot of the proportion of cells excited by GABA in different cell types at P7 (36 cells). $C$ : summary plot of the excitatory force for GABA (i.e., the difference between $E_{\mathrm{GABA}}$ and $V_{\text {thr }}$ ) in different cell types at $\mathrm{P} 7$ (54 cells). $D$ : whole cell recordings in a $\mathrm{L} 2 / 3$ pyramidal cell and an interneuron. The pipette solution contained $20 \mathrm{mM} \mathrm{Cl}^{-}$ that corresponded to $E_{\mathrm{GABA}}$ of about $-49 \mathrm{mV}$ (shown by dash lines on the figure). Nevertheless, GABAergic postsynaptic potential (PSP) values recorded at the soma considerably exceeded $E_{\mathrm{GABA}}$ and readily induced action potentials (APs).

observed in all cortical layers, spontaneous activity of neurons in deep layers was generally associated with oscillations. This is because of important intrinsic differences between $E_{\mathrm{m}}$ and $V_{\mathrm{thr}}$ in neuronal populations. $E_{\mathrm{m}}$ and $V_{\mathrm{thr}}$ are cell type specific, and the membrane voltage deviations required for neuron activation by synaptic input vary in different neuron typesfrom $\sim 20$ to $>50 \mathrm{mV}$-suggesting major differences in intrinsic excitability. Strong excitatory GABA signaling in combination with high intrinsic excitability of deep layer neurons generates a coherent network-driven activity in the immature neocortex. This convergence seems to be the main conditioning factor for selective generation of cGDPs by layer $5 / 6$ neurons. Oscillations typically remain confined to deep neocortical layers, requiring recurrent excitatory loops of pyramidal neurons and interneurons.

\section{GABAergic transmission is strongly depolarizing over the first postnatal week}

To directly determine the action of GABA, we recorded NMDA- and GABA-activated channels in the same neuron (Fig. 1) that provide $E_{\mathrm{GABA}}$ in absolute values. With this technique, we can compare alterations in $D F_{\mathrm{GABA}}$ across neuronal populations and different developmental stages. We found that $E_{\mathrm{GABA}}$ is $>20 \mathrm{mV}$ more depolarized than $E_{\mathrm{m}}$ at P7-P8 in neurons of all cortical layers. Thus the GABAergic transmission provides depolarizing drive to quiescent neurons. For pyramidal neurons, the developmental profile of $E_{\mathrm{GABA}}$ showed gradual depolarization at earlier ages (Fig. 2A), and GABA was still depolarizing at the end of second postnatal week. The shift in the mode of GABA action occurs most likely within the second week of life.

After the first postnatal week, $E_{\mathrm{m}}$ of principal cells in all layers did not differ significantly and stabilized at a negative level of about $-80 \mathrm{mV}$ (see Fig. $2 A$ ). In contrast to hippocampal neurons recorded with the same techniques (Tyzio et al. 2003, 2006), $E_{\mathrm{m}}$ of cortical neurons showed a developmentally regulated trend to more hyperpolarized potentials in both $\mathrm{L} 5 / 6$ and L2/3 pyramidal cells (Fig. 2A). This shift is chloride dependent, since bumetanide, which reduces $\left[\mathrm{Cl}^{-}\right]_{\mathrm{i}}$ by blocking activity of NKCC1 (Dzhala et al. 2005; Hannaert et al. 2002), mimicked the age-dependent hyperpolarization: $E_{\mathrm{m}}$ was hyperpolarized by $\sim 10 \mathrm{mV}$ at $\mathrm{P} 4$ and by $\sim 5 \mathrm{mV}$ at P7/8 (Fig. $2 B$ ). Although further experiments are required to explain the underlying mechanism, it is possible that GABA-induced tonic current modulates $E_{\mathrm{m}}$ in immature neurons as it regulates pyramidal cell excitability in adult somatosensory cortex (Salin and Prince 1996; Yamada et al. 2007).

Earlier studies have measured $D F_{\mathrm{GABA}}$ using the gramicidin perforated-patch technique and reported values of $<15 \mathrm{mV}$ (Owens et al. 1996; Yamada et al. 2004) or even hyperpolarizing (Daw et al. 2007b; Yamada et al. 2004) before the end of first postnatal week. The differences with these observations may be explained by significant errors introduced by invasive recording techniques. Indeed, the correct estimation of $E_{\mathrm{m}}$ is of a primary importance for showing the mode of GABA action, 
A
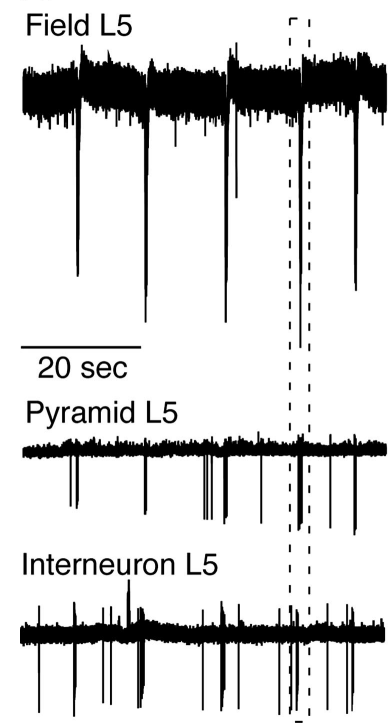

B

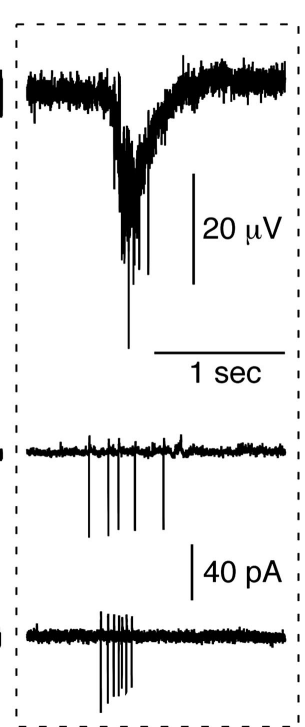

C

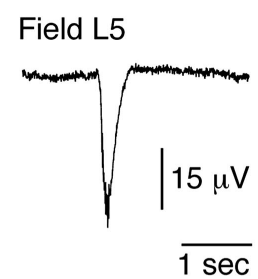

Field L4

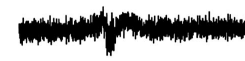

Field L5

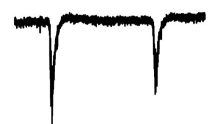

.

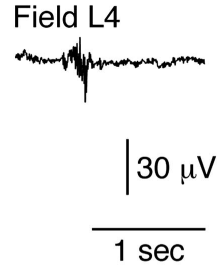

St L4

Pyr L2/3

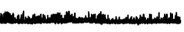

(1)

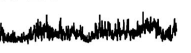

$15 \mathrm{pA}$

St L4
D

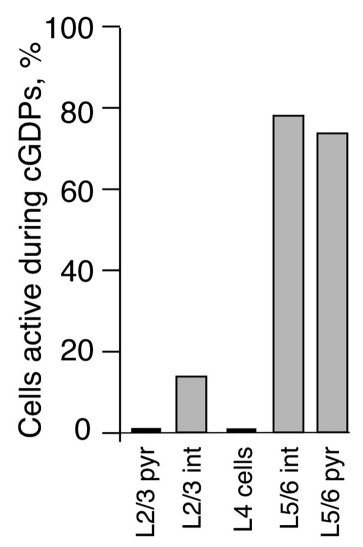

FIG. 5. Cortical giant depolarizing potentials (GDPs) - the principal pattern of activity in the neonatal neocortex in vitro is generated by deep cortical layers. A: L5 local field potential (top) and cell-attached recordings from an L5 pyramidal cell (middle) and an interneuron (bottom) in a P8 mouse neocortical slice. cortical GDP (cGDP) outlined with a dashed line is shown on the right panel at expanded time scale. $B$ : simultaneous field recordings at different layers indicate that oscillations are most powerful in L5/6 (top), much smaller in L4 (middle), and nearly absent in L2/3 (bottom). C: dual cell-attached recordings in combination with field ones in L2/3 (left) and L4 (right). Cells in L2/3 and L4 are quiescent during cGDPs. Field recordings in $B$ and $C$ are low-pass filtered at $100 \mathrm{~Hz}$. $D$ : proportion of active cells during cGDPs in different layers at P7-P8.

be it inhibitory or excitatory. The high-input resistance of immature neurons introduces significant errors in measurements of $E_{\mathrm{m}}$ in whole cell or gramicidin perforated-patch recordings (Tyzio et al. 2003). We tested these effects directly in neocortical neurons by performing a dual recording from the same neuron with cell-attached single channel and whole cell pipettes. $E_{\mathrm{m}}$ measured with single NMDA channels was about $-80 \mathrm{mV}$, but once an additional whole cell recording electrode was added, $E_{\mathrm{m}}$ depolarized by $>20 \mathrm{mV}$ and reached a value of $56 \mathrm{mV}$ (Tyzio et al. 2008). Clearly, $E_{\mathrm{m}}$ of immature neocortical neurons differs when measured by noninvasive or invasive techniques. This also confirms the validity of single channel recordings that provides a reliable estimation of $E_{\mathrm{m}}$. An alternative invasive recording technique-the gramicidin perforated patch-avoids the direct dialysis of internal chloride but may indirectly change $\left[\mathrm{Cl}^{-}\right]_{\mathrm{i}}$ via modification of $\left[\mathrm{Na}^{+}\right]_{\mathrm{i}}$ and $\left[\mathrm{K}^{+}\right]_{\mathrm{i}}$. It is worth noting that $\left[\mathrm{Cl}^{-}\right]_{\mathrm{i}}$ depends on the activity of NKCC1 and KCC2 co-transporters, which in turn are sensitive to alterations in $\left[\mathrm{Na}^{+}\right]_{\mathrm{i}}$ or $\left[\mathrm{K}^{+}\right]_{\mathrm{i}}$ (Brumback and Staley 2008; for review, see Adragna et al. 2004; Payne et al. 2003).

\section{Deep layer pyramidal neurons are more excitable than superficial ones}

Despite its generally strong depolarizing action, the GABAergic transmission generates APs in some interneuron subtypes and in deep but not superficial layer pyramidal neurons (Fig. 4). We observed significant variations of $E_{\mathrm{m}}$ and $V_{\mathrm{thr}}$ across different cell types. At P7-P8, concomitant with the maximum intensity of cGDPs, the voltage deviation required for activating L2/3 pyramidal or L4 stellate cells is $15 \mathrm{mV}$ larger than that for L5/6 pyramidal cells (Fig. 3D). Also, the $V_{\text {thr }}$ values for some subtypes of interneurons in L2/3 and L5/6 are very negative (Fig. 3, $A$ and $B$ ) making these cells highly excitable. This is also the case for most L5/6 pyramidal cells compared with those in L2/3. Therefore although L5/6 interneurons are able to create excitatory loops with pyramidal cells, in L2/3, this seems not to be possible. It is important to stress that, although $E_{\mathrm{GABA}}$ is often not more negative than the spike threshold, its driving force is sufficient to generate action potentials because of activation of voltage-gated currents (Fig. 4D).

Results also indicated that $V_{\text {thr }}$ is progressively shifted during maturation to more hyperpolarized values. Similar developmental shift has been reported previously in L5 pyramidal neurons of the medial entorhinal cortex (Reboreda et al. 2007) and prefrontal cortex (Zhang 2004). The underlying mechanisms are not known but are consistent with the progressive maturation of $\mathrm{Na}^{+}$and $\mathrm{K}^{+}$channels (Picken Bahrey and Moody 2003; for review, see Moody and Bosma 2005). Interestingly, despite the large driving force of GABA in the very immature neurons (P3), the excitatory action of GABA was not observed. Indeed, synaptic stimulation failed to initiate APs in pyramidal cells at P3 $(n=5)$ and activated only one of four interneurons tested. This is most likely because of a small density of sodium channels and corresponding low excitability of these neurons. In fact, we could not determine the threshold of action potential generation in these neurons since the input resistance is very high $(>1$ Gohm).

Therefore the developmental and cell type variations of $E_{\mathrm{m}}$ and $V_{\text {thr }}$ underlie higher excitability of deep layer neurons.

\section{Deep cortical layers generate GABA-driven cGDPs}

A variety of spontaneous patterns have been observed in neocortical slices (Aguilo et al. 1999; Corlew et al. 2004; Dupont et al. 2006; Garaschuk et al. 2000; Yuste et al. 1992)., However, cGDPs differ from activity patterns reported in the developing neocortex previously, in their temporal/spatial parameters and generating mechanisms. Thus cGDPs dominate neocortical activity around the end of first postnatal week, 

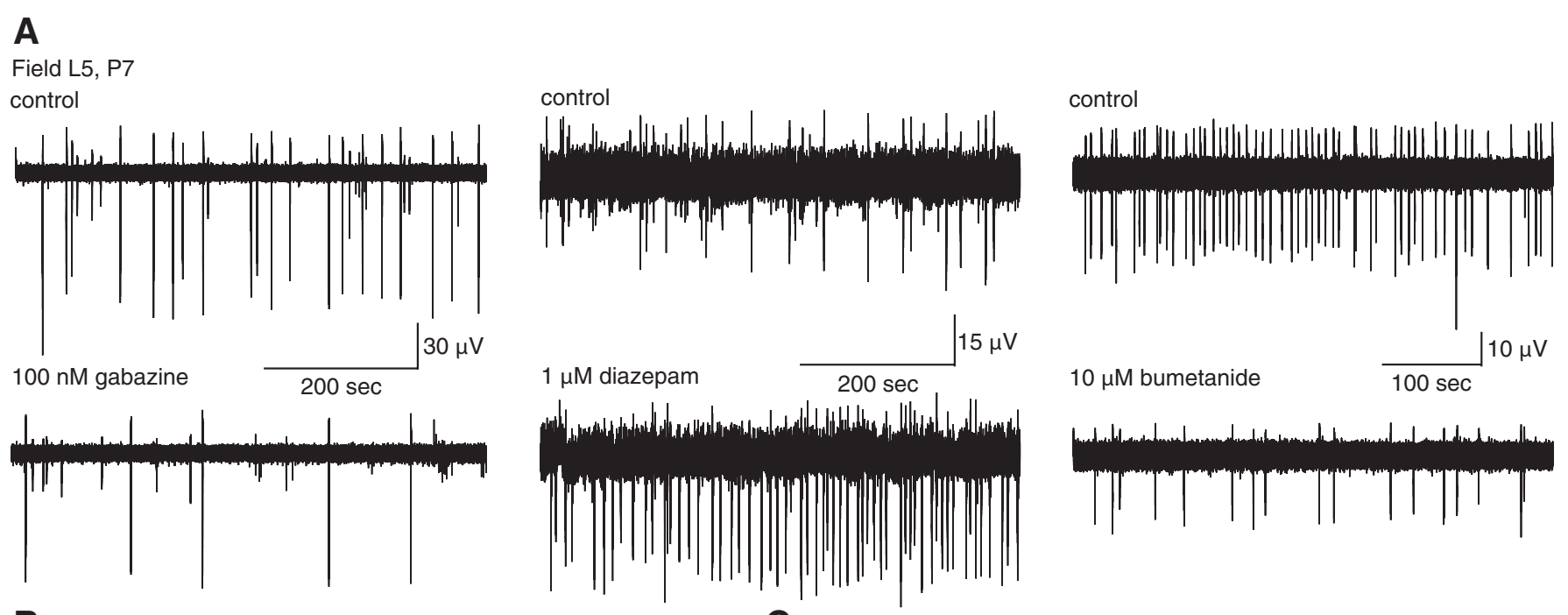

B

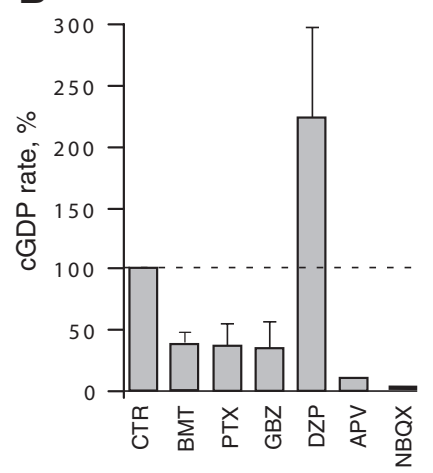

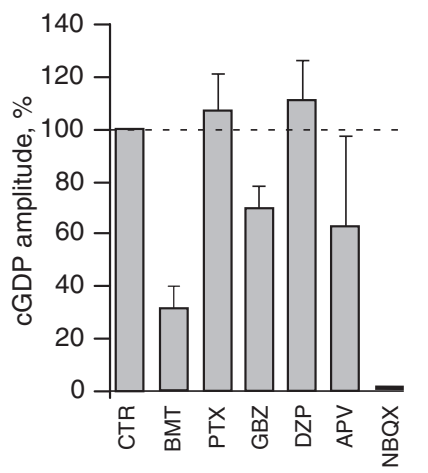

C

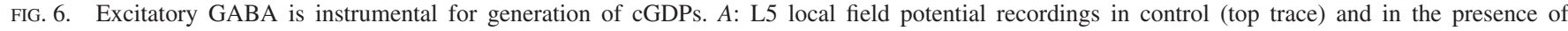

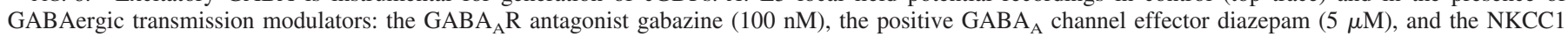

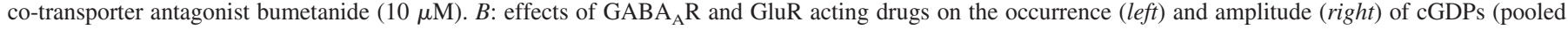

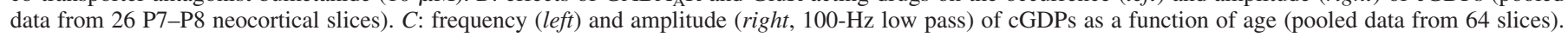

contrasting with earlier patterns that peak at birth and disappear shortly after, like the synapse-independent coherent activity (Corlew et al. 2004; Yuste et al. 1992) or the layer 1-correlated activity (Aguilo et al. 1999).

In addition, cGDPs differ from the early cortical networks oscillations (ENOs, Adelsberger et al. 2005; Garaschuk et al. 2000) since (1) ENOs peak at P1-P2 and disappear at P5-P6, whereas cGDPs are not observed before P4, peak at P7-P9, and disappear at about P13; (2) ENOs occur at very low rates (approximately once per 1-12 min), whereas cGDPs are observed once per 6-40 s at P7-P9; (3) ENOs involve the entire network of neurons whereas cGDPs are generated by deep cortical layers; and (4) $\mathrm{GABA}_{\mathrm{A}}$ Rs are not involved in the ENOs initiation; in contrast, cGDPs are inhibited by selective $\mathrm{GABA}_{\mathrm{A}} \mathrm{R}$ antagonists and bumetanide and are enhanced by diazepam (Fig. 6). CGDPs also differ from the recently described carbachol-induced oscillations (Dupont et al. 2006) that have a much longer duration, a propagation to the entire cortical mantle, and, across all layers, an initial dependence on gap junctions and subsequently on NMDA but not GABA receptors.

The sequential maturation of central oscillations has been systematically studied recently in the developing hippocampus by fast dynamic imaging techniques (Crepel et al. 2007). Around delivery, the gap junction interconnected small cell assemblies generate nonsynaptically induced calcium signals [synchronous plateau assemblies (SPA)] followed, at the end of first postnatal week, by synapse-driven GDPs (Crepel et al. 2007). SPAs coexist with GDPs during a transient developmental stage. However, an increase in occurrence of GDPs correlates with the decrease in SPA activity. Therefore the initial synapse-driven oscillations in hippocampus are preceded by nonsynapse driven patterns. Further studies are required to find out whether a similar developmentally regulated sequence exists in the immature neocortex as well.

The relevance of cGDPs to in vivo patterns remains to be determined. In the neonatal rat neocortex in vivo, the dominant pattern of electrical activity is spindle bursts. This transient coordinated activity controls the organization and shaping of sensory and motor systems (Dupont et al. 2006; Khazipov et al. 2004b; Minlebaev et al. 2006). Delta-brushes, observed in human preterm neonates, may represent the alike pattern in humans playing a similar role during formation of sensorimotor maps (Milh et al. 2007). Although cGDPs and spindle bursts share certain common features, it is difficult to directly test this hypothesis in the motor cortex since functional thalamocortical connections are needed. Thalamocortical slices are available for the barrel, visual, auditory, and anterior cingulate cotices (Agmon and Connors 1991; Cruikshank et al. 2002; Daw et al. 2007a,b; Lee et al. 2007; MacLean et al. 2006) but not the motor cortex. Interestingly, we found that glutamate puffs in thalamocortical slices of the barrel 
cortex (Agmon and Connors 1991) generate spindle-burst-like oscillations (P7 mice; data not shown). Thus thalamic input can initiate oscillations in deep neocortical layers, at least in the barrel cortex.

Thus our results indicate that GABA depolarizes and excites neocortical neurons in an age-, layer-, and type-specific manner and that excitatory GABA plays an important role in generation of endogenous pattern of cGDPs in the developing neocortical networks. This is in agreement with our more general hypothesis that, early in development, neuronal networks generate specific patterns of activity driven by depolarizing GABA (Ben-Ari 2002; Ben-Ari et al. 2007). We suggest that cGDPs, which provide coordinated activation of neocortical neurons and thus stimulate synaptic plasticity, participate in the activity-dependent formation of neocortical circuitry.

\section{A C K N O W LED GMENTS}

We thank I. Jorquera for technical assistance in histological processing.

\section{G R A N T S}

This work was supported by Institut National de la Santé et de la Recherche Médicale and grants from Fondation pour la Recherche Médicale, Agence Nationale de la Recherche 2005 Neurosciences, neurologie et psychiatrie and European Council LSH-CT-2006-037315 (EPICURE) FP6-Thematic priority LIFESCIHEALTH.

\section{REFERENCES}

Adelsberger H, Garaschuk O, Konnerth A. Cortical calcium waves in resting newborn mice. Nat Neurosci 8: 988-990, 2005.

Adragna NC, Di Fulvio M, Lauf PK. Regulation of K-Cl cotransport: from function to genes. J Membr Biol 201: 109-137, 2004.

Agmon A, Connors BW. Thalamocortical responses of mouse somatosensory (barrel) cortex in vitro. Neuroscience 41: 365-380, 1991.

Aguilo A, Schwartz TH, Kumar VS, Peterlin ZA, Tsiola A, Soriano E, Yuste R. Involvement of cajal-retzius neurons in spontaneous correlated activity of embryonic and postnatal layer 1 from wild-type and reeler mice. J Neurosci 19: 10856-10868, 1999.

Ben-Ari Y. Excitatory actions of gaba during development: the nature of the nurture. Nat Rev Neurosci 3: 728-739, 2002.

Ben-Ari Y. Basic developmental rules and their implications for epilepsy in the immature brain. Epileptic Disord 8: 91-102, 2006.

Ben-Ari Y, Cherubini E, Corradetti R, Gaiarsa JL. Giant synaptic potentials in immature rat CA3 hippocampal neurones. J Physiol 416: 303-325, 1989.

Ben-Ari Y, Gaiarsa JL, Tyzio R, Khazipov R. GABA: a pioneer transmitter that excites immature neurons and generates primitive oscillations. Physiol Rev 87: 1215-1284, 2007.

Brumback AC, Staley KJ. Thermodynamic regulation of NKCC1-mediated $\mathrm{Cl}$ - cotransport underlies plasticity of $\mathrm{GABA}(\mathrm{A})$ signaling in neonatal neurons. J Neurosci 28: 1301-1312, 2008.

Burgard EC, Hablitz JJ. Developmental changes in NMDA and non-NMDA receptor-mediated synaptic potentials in rat neocortex. J Neurophysiol 69: 230-240, 1993.

Cang J, Renteria RC, Kaneko M, Liu X, Copenhagen DR, Stryker MP. Development of precise maps in visual cortex requires patterned spontaneous activity in the retina. Neuron 48: 797-809, 2005.

Corlew R, Bosma MM, Moody WJ. Spontaneous, synchronous electrical activity in neonatal mouse cortical neurones. J Physiol 560: 377-390, 2004.

Crepel V, Aronov D, Jorquera I, Represa A, Ben-Ari Y, Cossart R. A parturition-associated nonsynaptic coherent activity pattern in the developing hippocampus. Neuron 54: 105-120, 2007.

Cruikshank SJ, Rose HJ, Metherate R. Auditory thalamocortical synaptic transmission in vitro. J Neurophysiol 87: 361-384, 2002.

Davies CH, Davies SN, Collingridge GL. Paired-pulse depression of monosynaptic GABA-mediated inhibitory postsynaptic responses in rat hippocampus. J Physiol 424: 513-531, 1990.

Daw MI, Scott HL, Isaac JT. Developmental synaptic plasticity at the thalamocortical input to barrel cortex: mechanisms and roles. Mol Cell Neurosci 34: 493-502, 2007a.
Daw NW, Ashby MC, Isaac JTR. Coordinated developmental recruitment of latent fast spiking interneurons in layer IV barrel cortex. Nat Neurosci 10: 453-461, 2007b.

Dupont E, Hanganu IL, Kilb W, Hirsch S, Luhmann HJ. Rapid developmental switch in the mechanisms driving early cortical columnar networks. Nature 439: 79-83, 2006.

Dzhala VI, Talos DM, Sdrulla DA, Brumback AC, Mathews GC, Benke TA, Delpire E, Jensen FE, Staley KJ. NKCC1 transporter facilitates seizures in the developing brain. Nat Med 11: 1205-1213, 2005.

Feller MB. Spontaneous correlated activity in developing neural circuits. Neuron 22: 653-656, 1999.

Franceschetti S, Sancini G, Panzica F, Radici C, Avanzini G. Postnatal differentiation of firing properties and morphological characteristics in layer V pyramidal neurons of the sensorimotor cortex. Neuroscience 83: 10131024, 1998.

Galli L, Maffei L. Spontaneous impulse activity of rat retinal ganglion cells in prenatal life. Science 242: 90-91, 1988.

Garaschuk O, Linn J, Eilers J, Konnerth A. Large-scale oscillatory calcium waves in the immature cortex. Nat Neurosci 3: 452-459, 2000.

Hanganu IL, Ben-Ari Y, Khazipov R. Retinal waves trigger spindle bursts in the neonatal rat visual cortex. J Neurosci 26: 6728-6736, 2006.

Hannaert P, Alvarez-Guerra M, Pirot D, Nazaret C, Garay RP. Rat NKCC2/NKCC1 cotransporter selectivity for loop diuretic drugs. Naunyn Schmiedebergs Arch Pharmacol 365: 193-199, 2002.

Häusser M, Major G, Stuart G. Differential shunting of EPSPs by action potentials. Science 291: 138-141, 2001.

Kandler K, Gillespie DC. Developmental refinement of inhibitory soundlocalization circuits. Trends Neurosci 28: 290-296, 2005.

Katz LC, Shatz CJ. Synaptic activity and the construction of cortical circuits. Science 274: 1133-1138, 1996.

Khazipov R, Esclapez M, Caillard O, Bernard C, Khalilov I, Tyzio R, Hirsch J, Dzhala V, Berger B, Ben-Ari Y. Early development of neuronal activity in the primate hippocampus in utero. J Neurosci 21: 9770-9781, 2001.

Khazipov R, Khalilov I, Tyzio R, Morozova E, Ben-Ari Y, Holmes GL. Developmental changes in GABAergic actions and seizure susceptibility in the rat hippocampus. Eur J Neurosci 19: 590-600, 2004a.

Khazipov R, Sirote A, Leinekugel X, Holmes GL, Ben-Ari Y, Buzsaki G. Early motor activity drives spindle bursts in the developing somatosensory cortex. Nature 432: 758-761, 2004b.

Lee CM, Chang WC, Chang KB, Shyu BC. Synaptic organization and input-specific short-term plasticity in anterior cingulate cortical neurons with intact thalamic inputs. Eur J Neurosci 25: 2847-2861, 2007.

Luhmann HJ, Prince DA. Postnatal maturation of the GABAergic system in rat neocortex. J Neurophysiol 65: 247-263, 1991.

MacLean JN, Fenstermaker V, Watson BO, Yuste R. A visual thalamocortical slice. Nat Methods 3: 129-134, 2006.

McCabe AK, Chisholm SL, Picken-Bahrey HL, Moody WJ. The selfregulating nature of spontaneous synchronized activity in developing mouse cortical neurones. J Physiol 577: 155-167, 2006.

McCormick DA, Prince DA. Post-natal development of electrophysiological properties of rat cerebral cortical pyramidal neurones. J Physiol 393: 743-762, 1987.

Meister M, Wong RO, Baylor DA, Shatz CJ. Synchronous bursts of action potentials in ganglion cells of the developing mammalian retina. Science 252: 939-943, 1991.

Milh M, Kaminska A, Huon C, Lapillonne A, Ben-Ari Y, Khazipov R. Rapid cortical oscillations and early motor activity in premature human neonate. Cereb Cortex 17: 1582-1594, 2007.

Minlebaev M, Ben-Ari Y, Khazipov R. Network mechanisms of spindleburst oscillations in the neonatal rat barrel cortex in vivo. J Neurophysiol 97: 692-700, 2006.

Moody WJ, Bosma MM. Ion channel development, spontaneous activity, and activity-dependent development in nerve and muscle cells. Physiol Rev 85: 883-941, 2005.

Owens DF, Boyce LH, Davies CH, Kriegstein AR. Excitatory GABA responses in embryonic and neonatal cortical slices demonstrated by gramicidin perforated-patch recordings and calcium imaging. J Neurosci 16: 6414-6423, 1996.

Owens DF, Kriegstein AR. Patterns of intracellular calcium fluctuation in precursor cells of the neocortical ventricular zone. J Neurosci 18: 53745388, 1998.

Owens DF, Liu X, Kriegstein AR. Changing properties of GABAA receptormediated signaling during early neocortical development. J Neurophysiol 82: $570-583,1999$. 
Payne JA, Rivera C, Voipio J, Kaila K. Cation-chloride co-transporters in neuronal communication, development and trauma. Trends Neurosci 26: 199-206, 2003

Picken Bahrey HL, Moody WJ. Early development of voltage-gated ion currents and firing properties in neurons of the mouse cerebral cortex. J Neurophysiol 89: 1761-1773, 2003.

Reboreda A, Raouf R, Alonso A, Seguela P. Development of cholinergic modulation and graded persistent activity in layer $\mathrm{v}$ of medial entorhinal cortex. J Neurophysiol 97: 3937-3947, 2007.

Rheims S, Represa A, Ben-Ari Y, Zilberter Y. Layer-specific generation and propagation of seizures in slices of developing neocortex: role of excitatory GABAergic synapses. J Neurophysiol doi:10.1152/jn.90403.2008.

Salin PA, Prince DA. Spontaneous GABAA receptor-mediated inhibitory currents in adult rat somatosensory cortex. J Neurophysiol 75: 1573-1588, 1996.

Tyzio R, Cossart R, Khalilov I, Minlebaev M, Hubner CA, Represa A, Ben-Ari Y, Khazipov R. Maternal oxytocin triggers a transient inhibitory switch in GABA signaling in the fetal brain during delivery. Science 314: 1788-1792, 2006.

Tyzio R, Ivanov A, Bernard C, Holmes GL, Ben-Ari Y, Khazipov R. Membrane potential of CA3 hippocampal pyramidal cells during postnatal development. J Neurophysiol 90: 2964-2972, 2003.
Tyzio R, Minlebaev M, Rheims S, Ivanov A, Jorquera I, Holmes GL, Zilberter Y, Ben-Ari Y, Khazipov R. Postnatal change in somatic GABA signaling in the rat hippocampus. Eur J Neurosci 27: 2515-2528, 2008.

Williams SR, Stuart GJ. Voltage- and site-dependent control of the somatic impact of dendritic IPSPs. J Neurosci 23: 7358-7367, 2003.

Yamada J, Furukawa T, Ueno S, Yamamoto S, Fukuda A. Molecular basis for the GABAA receptor-mediated tonic inhibition in rat somatosensory cortex. Cereb Cortex 17: 1782-1787, 2007.

Yamada KA, Okabe A, Toyoda H, Kilb W, Luhmann HJ, Fukuda A. $\mathrm{Cl}$ - uptake promoting depolarizing GABA actions inimmature rat neocortical neurones is mediated by NKCC1. J Physiol (Lond) 557: 829$841,2004$.

Yuste R, Peinado A, Katz LC. Neuronal domains in developing neocortex. Science 257: 665-669, 1992.

Zhang ZW. Maturation of layer $\mathrm{V}$ pyramidal neurons in the rat prefrontal cortex: intrinsic properties and synaptic function. J Neurophysiol 91: 11711182, 2004.

Zhou FM, Hablitz JJ. Postnatal development of membrane properties of layer I neurons in rat neocortex. J Neurosci 16: 1131-1139, 1996. 